\title{
ФАКТОРИ ВИЗНАЧЕННЯ ПЕДАГОГІЧНИХ УМОВ ОРГАНІЗАЦІЇ ОСВІТНЬОГО ПРОЦЕСУ В ЗАКЛАДАХ ВИЩОЇ ОСВІТИ
}

\author{
Володимир Стешенко \\ доктор педагогічних наук, професор, завідувач кафедри \\ педагогічки і методики технологічної та професійної освіти \\ ДВНЗ «Донбаський державний педагогічний університет» \\ м. Слов'янськ, Україна \\ steshenko.volodymyr@gmail.com \\ Богдан Стешенко \\ кандидат педагогічних наук \\ м. Слов'янськ Донецької області, Україна
}

Анотація. Проаналізовано розуміння вченими понять: «умови» та «педагогічні умови». Розглянуто підходи до розуміння поняття «педагогічні умови». Установлено, що поняття «педагогічні умови» слід трактувати як обставини/причини, які обумовлюють/визначають ефективне (нормальне) функціонування предмета дослідження; визначати педагогічні умови в кожному конкретному випадку необхідно з урахуванням діяльнісного, системного та інших методологічних підходів; при виборі певних педагогічних умов слід ураховувати відповідні фактори (підстави) їхньої наявності; такими факторами виступають провідні види освітньої діяльності, що підлягають дослідженню в кожному конкретному випадку; усі умови формування певних якостей або утворень у студентів доцільно представляти відповідно до здійснюваної освітньої діяльності: соціально-виховної, організаційної, дидактичної, методичної або їхніми поєднаннями; при виборі педагогічних умов у наукових роботах необхідно спиратися на вказані фактори їхнього визначення.

Ключові слова: вища освіта; освітній процес; педагогічні умови; умови; фактори (підстави) педагогічних умов.

Постановка проблеми в загальному вигляді. Відомо, що освітня діяльність у закладах вищої освіти (ЗВО) передбачає набуття студентами високого рівня загального інтелектуального розвитку (зокрема оволодіння такими якостями, як сприйняття, пам'ять, мислення, увага, логічні операції тощо) та високого рівня володіння спеціальними особистісними (складними способами інтелектуальної діяльності, мужністю, кмітливістю, чіткістю думок, акуратністю, швидкістю реакції тощо) й функціональними професійними (загальними та фаховими компетентностями, ініціативністю тощо) якостями тощо. Отже, щоб студенти оволоділи цими та іншими якостями, необхідно створювати у ЗВО відповідні умови, наповнювати освітню діяльність такими подіями, які б могли забезпечити їхнє формування. Це $\epsilon$ одна 3 вимог методологічного діяльнісного підходу.

Аналіз останніх досліджень i публікацій. Проблемі визначення різноманітних педагогічних та інших умов ефективного забезпечення освітнього процесу присвячено праці багатьох учених як минулого століття
(Ю. Бабанський,
В. Беспалько,
В. Свдокимов,
М. Зверева,
В. Оконь, 
Фактори визначення педагогічних умов організації освітнього процесу в закладах вищої освіти

I. Прокопенко, В. Сластьонін, Т. Шамова та ін.), так і сучасних (А. Алексюк, П. Підкасістий, С. Сапожніков, В. Стрельніков, Б. Чижевський та ін.). Зміст поняття «педагогічні умови» розкривали В. Андрєєв, Н. Жукович-Дородних, I. Зимня, С. Іванченко, Л. Максимчук, О. Набока, А. Семенова та ін.

Формулювання цілей статті. Найбільш докладний аналіз поняття «педагогічні умови» ми знаходимо в працях Н. Іпполітової, Н. Тверезовської та ін., де відзначалось, що в педагогічних дослідження це поняття використовувалось досить широко. Також у літературі знаходимо, що відповідно до мети дослідження науковці визначали різні умови: соціальні, педагогічні, психологічні, дидактичні, методичні, організаційні тощо. Для цього вони використовували відповідні фактори (підстави), які часто бували не досить обгрунтованими. У зв'язку з цим виникла необхідність встановити, які ж фактори мають обумовлювати вибір педагогічних умов організації освітнього процесу у ЗВО.

Результати дослідження. Почнемо з визначення поняття «умови». Так, у Педагогічному енциклопедичному словнику [3] поняття «умови» трактується як сукупність об'єктів (речей, процесів, відносин тощо), необхідних для виникнення, існування або зміни цього об'єкта. На основі різних типів законів виділяються різні типи умов: структурні, функціональні тощо. Зазначається, що історично умови розумілися лише як обставини, при яких здійснюється подія. Тому розробка категорії «умови» велася передусім у теорії причинності i, як правило, не спеціально, а в зіставленні 3 категоріями причини і результату. При цьому причину розглядали включеною в число достатніх умов, які відрізнялися більшою активністю, незалежністю дії та іншими характеристиками.

У словнику також зазначається, що таке трактування поняття «умови» не збігається із звичайно вживаними як його синоніми поняттями: «середовище», «обставини», «обстановка». По-перше, поняття: «середовище», «обставини», «обстановка» відображають повну сукупність об'єктів, що становлять «оточення» об'єкта. По-друге, ці поняття відображають лише ті обставини, які $\epsilon$ зовнішніми стосовно об'єкта, тоді як в число умов нерідко входять і внутрішні характеристики самого об'єкта.

У філософії «умова» позначає відношення предмета до навколишньої дійсності, явищ об'єктивної реальності, а також щодо себе і свого внутрішнього світу. Досліджуваний об'єкт виступає як щось обумовлене, а умова - як відносно зовнішне до предмета пізнання різноманіття об'єктивного світу. Тобто умова визначається як сукупність причин (об'єктів, процесів, відносин тощо), необхідних для виникнення, існування або зміни певного досліджуваного об'єкта. Але при цьому умову слід відрізняти від поняття «причина», бо причина безпосередньо породжує певне явище або процес, а умова обумовлює те середовище, у якому виникають, існують і розвиваються ці явища або процеси.

У логіці та математиці умови - це фактори, які встановлюють залежність істинності будь-якого твердження від наявності іншого затвердження. Необхідними умовами виступають твердження, без яких розглядуване явище не 
Фактори визначення педагогічних умов організації освітнього процесу в закладах вищої освіти

може бути істинним. Достатніми називають такі умови, при наявності (виконанні, дотриманні) яких твердження набуває істинності. При цьому умови можуть бути необхідними, але недостатніми, достатніми, але не необхідними, необхідними і достатніми.

У Словнику української мови «умова» визначається в різних варіантах: 1) взаємна усна чи письмова домовленість про що-небудь; угода, договір; 2) вимога, пропозиція, які висуваються однією із сторін, що домовляються про що-небудь, а також при укладанні угоди, договору; 3) необхідна обставина, яка робить можливим здійснення, створення, утворення чого-небудь або сприяє чомусь; 4) обставини, особливості реальної дійсності, при яких відбувається або здійснюється що-небудь; 5) правила, які існують або встановлені в тій чи тій галузі життя, діяльності, які забезпечують нормальну роботу чого-небудь; 6) сукупність даних, положення, що лежать в основі чого-небудь [10, с. 441].

3 огляду на вищевикладене поняття «умови» слід розуміти як обставини/причини, які обумовлюють/визначають ефективне (нормальне) функціонування предмета дослідження. У вищій освіті умови організації освітньої діяльності мають забезпечувати як можливість студенту стати спеціалістом, так і розвиватися та накопичувати власний індивідуальний потенціал у процесі поступального саморозвитку.

Очевидно, що умови організації освітнього процесу обумовлюються певними факторами. Одним із таких факторів $є$ психологічні особливості студентського віку. Так, психологами встановлено, що в період дорослості (пізньої юності - ранньої зрілості) відбувається посилення соціального розвитку особистості шляхом включення її в різні сфери суспільних відносин і діяльності. Процес особистісного розвитку студента залежить від рівня його соціальної активності та ступеня продуктивності, який здійснюється в умовах системи вищої освіти - соціального мікросередовища.

Іншим фактором є соціальне середовище. У довідковій літературі поняття середовища визначається як сукупність умов існування людини та суспільства. Під соціальним середовищем у соціології розуміють економічні, педагогічні, політичні, соціальні, духовні, територіальні умови, що впливають на становлення особистості. Соціальне середовище включає суспільні (матеріальні та духовні) умови становлення, існування, розвитку та діяльності людей, які тісно пов'язані з суспільними відносинами, у які ці люди включені. Так, заклад вищої освіти має створювати освітнє середовище, яке визначається відповідними соціальними умовами, що впливають на становлення особистості студента.

У педагогіці частіше використовується поняття «соціально-педагогічні умови», які більшість дослідників поділяе за функціями на загальні та специфічні. Так, загальні соціально-педагогічні умови визначають як такі обставини педагогічного процесу, що сприяють гуманізації виховного середовища, формуванню культурних цінностей студента, забезпеченню 
толерантного відношення в групі тощо. До них відносять соціальні, культурні, етнічні тощо.

Специфічні соціально-педагогічні умови вчені трактують як такі обставини, що сприяють створенню надійної системи управління міжособистісними зв'язками, організації набуття позитивного досвіду взаємодії 3 подальшим розвитком системи цінностей у майбутніх фахівців тощо. Це моральний клімат у студентській групі, стан комунікаційної сфери на факультеті, спрямованість інформаційного та культурного середовища тощо. Водночас учені виділяють зовнішні соціальні умови, що відображають характер взаємодії в системі педагог-студент, студент-ЗВО, та внутрішні, що являють собою самоусвідомлення суб'єктом ціннісної сутності творчої, професійної, педагогічної діяльності, їі результатів і наслідків. Але переважно в педагогіці вчені досліджують педагогічні, організаційно-педагогічні, методичні, організаційно-методичні умови здійснення освітнього процесу або професійного становлення майбутнього спеціаліста. Відповідно маємо й різноманітність факторів їхнього визначення.

У Педагогічному словнику поняття «педагогічні умови» розглядаються як певні обставини чи обстановки, що впливають на формування й розвиток педагогічних явищ, процесів, систем, якостей особистості [4, с. 97]. Так, «педагогічні умови» вчені визначають як обставину або подію, що впливає на формування та розвиток педагогічних явищ, систем, процесів, якостей особистості.

Детальний аналіз цього поняття було надано В. Андреєвим [1, с. 124]. Він зазначав, що педагогічні умови $\epsilon$ результатом цілеспрямованого відбору, конструювання та застосування таких елементів, як зміст, методи, прийоми та організаційні форми навчання для досягнення педагогічних цілей. Водночас відзначалося, що педагогічні умови мають подвійну властивість. Перша відповідає наявності певної «атмосфери» освітнього процесу (тому упорядкованість, логічність, структурованість цього процесу вливає на ефективність створених педагогічних умов). Друга властивість полягає в тому, що педагогічні умови є джерелом виникнення, а отже, й існування, розвитку та регулювання педагогічного процесу, та виступають гарантом його присутності.

У роботах Н. Тверезовської, Л. Лісовської, Л. Філіпової [11] педагогічні умови визначаються як взаємозалежні чинники, які складають сукупності найбільш оптимального середовища для максимального засвоєння учнями знань, формування вмінь і навичок.

Досить глибоко опрацювали поняття «педагогічні умови» Н. Іпполітова та Н. Стерхова [5]. Вони встановили, що поняття «умова» є загальнонауковим i представляє сукупність причин, обставин, будь-яких об'єктів, що впливають на функціонування та розвиток будь-якого об'єкта (зокрема педагогічної системи, цілісного педагогічного процесу); педагогічні умови, виступаючи як один із компонентів педагогічної системи, відображають сукупність можливостей освітнього та матеріально-просторового середовища, що впливають на 
особистісний і процесуальний аспекти цієї системи, й забезпечують її ефективне функціонування та розвиток. Дослідники виділяють різні види педагогічних умов, що забезпечують функціонування та ефективний розвиток педагогічної системи, серед яких найбільш часто зустрічаються організаційно-педагогічні, психолого-педагогічні, дидактичні. Організаційно-педагогічні умови являють собою сукупність цілеспрямовано сконструйованих можливостей змісту, форм, методів цілісного педагогічного процесу (заходів впливу), що лежать в основі управління функціонуванням і розвитком процесуального аспекту педагогічної системи (цілісного педагогічного процесу). Психолого-педагогічні умови - це сукупність цілеспрямовано сконструйованих взаємопов'язаних i взаємообумовлених можливостей освітнього та матеріально-просторового середовища (заходів впливу), що спрямовані на розвиток особистісного аспекту педагогічної системи (перетворення конкретних характеристик особистості). Дидактичні умови виступають як результат цілеспрямованого відбору, конструювання та застосування елементів змісту, методів (прийомів), а також організаційних форм навчання для досягнення дидактичних цілей.

Отже, можна стверджувати, що педагогічні умови визначають цілісність педагогічного процесу, адекватність змісту навчання до педагогічної практики; організацію діяльності викладача; певний педагогічний досвід. Вони сприяють оволодінню студентом теоретичним багажем знань і практичним досвідом; уведенню його в поле професійних відносин; формуванню та розвитку творчих здібностей, якостей організатора, умінь щодо самоорганізації, аналізу, оцінки, прийняття рішення та вирішення посталих проблем (прораховуванню) у різних ситуаціях.

Як різновид педагогічних умов деякі науковці розглядають організаційнопедагогічні. Так, наприклад, А. Стареєва [9] організаційно-педагогічні умови визначає через низку таких функцій: розробка та дотримання нормативноправового забезпечення процесу підготовки майбутнього вчителя; чітке планування і організація освітнього процесу у ЗВО згідно з кредитно-модульною технологією навчання; створення необхідного навчально-методичного забезпечення; контроль збоку кафедр за реалізацією освітньо-професійної програми та координація зусиль у цьому аспекті навчальної діяльності студентів; матеріально-технічне забезпечення відповідно до вимог кредитно-модульної організації навчання та сучасного інформаційного простору; належне кадрове забезпечення; науково-дослідна робота викладачів і студентів у контексті їхньої підготовки до майбутньої інноваційної професійної діяльності (тобто включення в практичну діяльність); формування активної життєвої позиції молоді в поєднанні з розумінням спільної належності засобами позааудиторної роботи; вивчення ринку праці для майбутніх випускників і перспектив його розвитку (зв'язки школа - університет).

Іншим різновидом педагогічних умов є дидактичні, які вчені пов'язують 3 організацією та управлінням пізнавальною діяльністю тих, хто навчається. Так, 
Фактори визначення педагогічних умов організації освітнього процесу в закладах вищої освіти

С. Остапенко [8] дидактичні умови розглядає як системоутворювальні чинники, що впливають на формування компонентів соціальної компетентності студентів. При їхньому виборі вона пропонувала враховувати такі вихідні позиції: а) двоєдину природу досліджуваного феномена: соціальної компетентності і синтезу здобутків компетентнісного підходу; б) загальнодидактичну специфіку самостійної освітньої діяльності студентів в умовах закладу вищої освіти; в) основні закономірності фахової підготовки студентів.

Окрім педагогічних, організаційно-педагогічних умов, учені досліджують й організаційно-методичні (В. Артемов, О. Набока та ін.). В. Артемов організаційно-методичні умови визначає як такі, що сприяють практичній реалізації певного педагогічного процесу та які включають: використання комплексу методів навчання, що відповідають задачам формування інформаційно-комунікативних умінь майбутніх фахівців і створення можливості для самостійної комунікативної діяльності студентів, у процесі якої відбувається оволодіння студентами професійними компетентностями [2]. О. Набока організаційно-методичні умови трактує як систему науково-методичних заходів університету, що підтримують реалізацію процесу впровадження професійноорієнтованих технологій - розроблення навчально-методичних комплексів та інших методичних матеріалів, що забезпечують діяльність студентів i викладацького складу» [6, с. $224-225]$.

Водночас учені досліджують окремо і методичні умови. Так, наприклад, О. Налімова [7] зазначає, що методичні умови сприяють успішному здійсненню освітнього процесу. Їхніми вихідними положеннями є дидактичні та методичні принципи. До загальних методичних умов вона відносить використання на заняттях алгоритмічних приписів, системи завдань інтерактивної направленості різного характеру та пізнавальних мотивів при формуванні інтересів тих, хто навчається.

Методичні умови в науковій літературі пов'язуються з організацією та здійсненням освітнього процесу й поділяються на три групи. Перша група умов обумовлює організацією занять, друга - організацією пізнавальної діяльності тих, хто навчається, третя - 3 управлінням пізнавальною діяльністю за допомогою методичних прийомів. Тобто методичні умови забезпечують оволодіння та практичне застосування отриманих студентами знань, набуття ними практичного досвіду, активний розвиток креативності та винахідливості (особистісних якостей) у процесі навчання та участі в різноманітних освітніх заходах.

Аналізуючи сутність і зміст педагогічних, організаційно-педагогічних, методичних, організаційно-методичних умов здійснення освітнього процесу чи професійного становлення майбутнього спеціаліста, які розробляють науковці, можемо визначитися 3 факторами (підставами), які їх обумовлюють. Це функціонування та розвиток педагогічного процесу або особистості; зміст, 
форми та методи навчання; дидактичні та методичні принципи; організація занять, пізнавальної діяльності, управління пізнавальною діяльністю тощо.

Коли ми розглянемо освітній процес із погляду педагогіки як науки та 3 огляду на сучасні методологічні підходи, зокрема діяльнісного і системного, то прийдемо до висновку про те, що всі умови, які забезпечують освітній процес, $\epsilon$ педагогічними, бо професійна підготовка майбутнього спеціаліста здійснюється в процесі освітньої діяльності; відповідно до діяльнісного підходу всі педагогічні умови обумовлюються провідними видами діяльності, що досліджуються, які і виступають у ролі факторів їхнього визначення; щодо системного підходу провідними видами діяльності в закладах освіти $\epsilon$ соціальна (виховна), організаційна, навчальна робота та їхнє поєднання; дидактичний і методичний аспекти організації навчальної діяльності є факторами визначення відповідних умов управління пізнавальною діяльністю студентів на заняттях і здійснення цієї діяльності.

Висновки $з$ дослідження і перспективи подальших розвідок у цьому напрямі. Отже, ми можемо зробити такі загальні висновки: педагогічні умови слід трактувати як обставини/причини, які обумовлюють/визначають ефективне (нормальне) функціонування предмета дослідження; усі умови, які мають відношення до освітнього процесу $\epsilon$ педагогічними; у кожному конкретному випадку педагогічні умови слід визначати 3 урахуванням діяльнісного, системного та інших методологічних підходів; при визначенні певних педагогічних умов необхідно враховувати відповідні фактори; факторами (підставами) визначення педагогічних умов виступають провідні види освітньої діяльності, які підлягають дослідженню; усі педагогічні умови формування певних якостей або утворень у студентів доцільно представляти відповідно до здійснюваної освітньої діяльності: соціально-виховної, організаційної, дидактичної, методичної або їхнім поєднанням; при виборі педагогічних умов у наукових роботах необхідно спиратися на вказані фактори їхнього визначення.

Оскільки ми наблизилися до класифікації педагогічних умов, то перспективними напрямами наших подальших наукових досліджень iз порушеної проблеми є створення їхньої таксономії.

\section{СПИСОК ВИКОРИСТАНИХ ДЖЕРЕЛ}

1. Андреев, В.И. (2000). Педагогика: учебный курс для творческого саморазвития. Казань, Россия: Центр инновационных технологий.

2. Артемов, В. Ю. (2015). Теоретичні та методичні основи формування деонтологічної компетентності фахівців із організачії захисту інформації з обмеженим доступом. (Дис. дра пед. наук). Київ, Україна.

3. Бим-Бад, Б.М. (2002). Педагогический энцииклопедический словарь. Москва, Россия.

4. Гончаренко, С. (1997). Український педагогічний словник. Київ, Україна: Либідь.

5. Ипполитова, Н. и Стерхова, Н. (б.д.). Анализ понятия «педагогические условия»: сущность, классификация. General and Professional Education, 1, 8-14.

6. Набока О. Г. (2012). Професійно-орієнтовані технологій навчання у фаховій підготовиі майбутніх економістів: теорія та методика застосування. Слов'янськ, Україна. 
Фактори визначення педагогічних умов організації освітнього процесу в закладах вищої освіти

7. Налимова, О. О. (2016). Методические условия организации интерактивного обучения естествознанию в 5 классе. Молодой ученьй, 6.1, 67-69.

8. Остапенко, С. А. (2012). Дидактичні умови формування соціальної компетентності студентів філологічних спеціальностей у процесі самостійної навчальної діяльності. Професійна підготовка: наукові записки НДУ ім. М. Гоголя. Серія: психолого-педагогічні науки, 1, 164-169.

9. Старєва, А. М. (б.д.). Організаційно-методичні умови підготовки майбутніх учителів суспільствознавчої галузі в контексті інноваційних процесів в освіті. Взято $3 \mathrm{http}: / / \mathrm{www} . \mathrm{e}-$ reading.ws/chapter.php/81556/46/Bogachkina_-_Psihologiya.html.

10. Білодід, І. К. (Ред.). (1970 - 1980). Словник української мови: в 11 т. Т. 10. Київ, Україна: Наукова думка.

11. Тверезовська, Н. Т. (2011). Організаційно-педагогічні умови формування фахових компетенцій організаторів виробництва у ЗВО I-II рівня акредитації. Науковий вісник Наи. унту біоресурсів і природокористування Украӥни, 159 (3), 261-265.

\title{
ФАКТОРЫ ОПРЕДЕЛЕНИЯ ПЕДАГОГІЧЕСКИХ УСЛОВИЙ ОРГАНИЗАЦИИ ОБРАЗОВАТЕЛЬНОГО ПРОЦЕССА В ЗАВЕДЕНИЯХ ВЫСШЕГО ОБРАЗОВАНИЯ
}

\author{
Владимир Стешенко \\ доктор педагогических наук, профессор, заведующий кафедрой \\ педагогики и методики технологического и профессионального образования \\ ГВУЗ «Донбасский государственный педагогический университет» \\ г. Славянск Украина \\ steshenko.volodymyr@gmail.com \\ Богдан Стешенко \\ кандидат педагогических наук \\ г. Славянск Донецкой области, Украина
}

Аннотация. Проанализированы определения понятий: «условия» и «педагогические условия», рассмотрены подходы ученых к пониманию понятия «педагогические условия». Установлено, что понятие «педагогические условия» следует трактовать как обстоятельства / причины, обуславливающие / определяющие эффективное (нормальное) функционирование предмета исследования; определять педагогические условия в каждом конкретном случае следует с учетом деятельностного, системного и других методологических подходов; при выборе конкретных педагогических условий необходимо учитывать соответствующие факторы; в качестве факторов (оснований) определения педагогических условий выступают ведущие виды образовательной деятельности, подлежащих исследованию в каждом конкретном случае; все педагогические условия формирования определенных качеств или образований студентов целесообразно представлять в соответствии с осуществляемой образовательной деятельностью: социально-воспитательной, организационной, дидактической, методической или их сочетаниями; при выборе педагогических условий в научных работах необходимо опираться на указанные факторы их определения.

Ключевые слова: высшее образование; образовательный процесс; педагогические условия; условия; факторы (основания) педагогических условий. 


\title{
FACTORS OF DETERMINING PEDAGOGICAL CONDITIONS OF EDUCATIONAL PROCESS ORGANIZATION IN HIGHER EDUCATION INSTITUTIONS
}

\author{
Volodymyr Steshenko \\ Doctor of Pedagogical Sciences, Professor, Head of the Department of \\ Pedagogy and Methodology of Technological and Vocational Education \\ SHEE "Donbas State Pedagogical University" \\ Slavyansk, Ukraine \\ steshenko.volodymyr@gmail.com \\ Bohdan Steshenko \\ Candidate of Pedagogical Sciences \\ Sloviansk, Donetsk region, Ukraine
}

\begin{abstract}
In the process of studying the essence and the content of the pedagogical, organizational and pedagogical, methodological, organizational and methodological conditions for conducting the educational process or the professional development of a future specialist, which are developed by scholars, it is established that pedagogical conditions are determined by scholars on the basis of certain factors that determine them. These factors include: the functioning and development of a teaching process; content, forms and methods of teaching; didactic and methodological principles; organization of classes, cognitive activity, and management of cognitive activity.

When considering the educational process from the point of view of pedagogy as a science and from the point of view of modern methodological approaches, in particular the activity and system, it has been discovered that all the conditions are pedagogical, since the professional training of a future specialist is carried out in the educational process; in terms of the activity approach, all pedagogical conditions are determined by the leading types of research activities, which act as factors of their determination. From the point of view of the systemic approach, the leading types of activities in educational institutions are: social (educational), organizational, educational work and their combination; didactic and methodical aspects of the organization of educational activities act as factors determining the appropriate conditions for managing students' cognitive activity in classes and the implementation of this activity.

As a result, the following general conclusions are made: pedagogical conditions should be interpreted as circumstances / reasons that determine the effective (normal) functioning of the subject of the study; all conditions that are relevant to the educational process are pedagogical; to determine pedagogical conditions in each case activity, system and other methodological approaches should be taken into account; when choosing certain pedagogical conditions it is necessary to take into account relevant factors. Such factors (foundations) are the leading types of educational activities that are to be investigated on a case-by-case basis; all pedagogical conditions for the formation of certain qualities or students' development should be presented in accordance with the educational activities carried out: social-educational, organizational, didactic, methodological or their combinations; when choosing pedagogical conditions in scientific works it is necessary to rely on the indicated and similar factors of their definition.
\end{abstract}

Key words: higher education; educational process; pedagogical conditions; conditions; factors (foundations) of pedagogical conditions.

\section{REFERENCES (TRANSLATED AND TRANSLITERATED)}

1. Andreev, V. I. (2000). Pedagogy: a training course for creative self-development. Kazan, Russia: Tsentr innovatsionnykh tekhnologiy. 


\section{В. СТЕШЕНКО, Б. СТЕШЕНКО}

Фактори визначення педагогічних умов організації освітнього процесу в закладах вищої освіти

2. Artemov, V. Yu. (2015). Theoretical and methodical principles of formation of deontological competence of specialists in the organization of protection of information with restricted access. (Doctoral dissertation). Kyiv, Ukraine.

3. Bim-Bad, B. M. (2002). Pedagogical Encyclopedic Dictionary. Moscow, Russia.

4. Honcharenko, S. (1997). Ukrainian Pedagogical Dictionary. Kyiv, Ukraine: Lybid.

5. Ippolitova, N. \& Sterkhova, N. (n.d.). Analysis of the concept of "pedagogical conditions": essence, classification. General and Professional Education, 1, 8-14.

6. Naboka, O. H. (2012). Professional-oriented technologies of training in the professional training of future economists: theory and method of application. Sloviansk, Ukraine.

7. Nalimova, O. O. (2016). Methodological conditions for the organization of interactive learning for natural science in grade 5. Molodoy uchenyy, 6.1, 67-69.

8. Ostapenko, S.A. (2012). Didactic conditions for the formation of social competence of students of philological specialties in the process of independent study activities. Profesiina pidhotovka: naukovi zapysky NDU im. M. Hoholia. Seriia: psykholoho-pedahohichni nauky, 1, 164169.

9. Statareva, A. M. (n.d.). Organizational-methodical conditions for the preparation of future teachers of the social science industry in the context of innovation processes in education. Retrieved from Access to the resource: http://www.e-reading.ws/ chapter.php / 81556/46 / Bogachkina _-_ Psihologiya.html.

10. Bilodid, I. K. (Ed.). (1970-1980). Dictionary of the Ukrainian language: in 11 vols. Vol. 10. Kyiv, Ukraine: Naukova dumka.

11. Tverezovska, N. T. \& Lisovska, L. M. (2011). Organizational-pedagogical conditions for the formation of professional competencies of the organizers of production in the ZOO of the I-II level of accreditation. Naukovyi visnyk Nats. Un-tu bioresursiv I pryrodokorystuvannia Ukrainy, 159 (3), 261-265. 